\title{
Pengaruh Motivasi Kerja Dan Kompensasi Guru Terhadap Kinerja Guru SMK Swasta Se-Kecamatan Bangil
}

\author{
Windasari \\ Manajemen Pendidikan Universitas Negeri Surabaya \\ windasari@unesa.ac.id \\ Muchammad Zulham Yahya \\ SMK Darut Tauhid Bangil \\ zulwamyahya27@gmail.com
}

\begin{abstract}
This research objective to find out the impact of motivation and compensation through teachers performance Vocational High School in Bangil district. Collecting data technique used questionnaire and distributed to respondent. Sampling technique is cluster random sampling. Sample for every school are 3 teachers from each major. Totally sample 42 respondents from 5 schools. Validity test used pearson product moment. Analisis technique to answer the research questions are inferential statistic multiple linier regression. Research results showed motivation and compensation have an impact through teachers performance Vocational High School in Bangil District.
\end{abstract}

Keywords: Motivation, Compensation, Performance, Teachers

\section{Article Info}

Received date: 3 Oktober $2019 \quad$ Revised date: 28 November $2019 \quad$ Accepted date: 20 Desember 2019

\section{PENDAHULUAN}

Pendidikan memiliki peranan penting dalam mencerdaskan manusia. Berdasarkan Undang-Undang Nomor 20 tahun 2003 tentang Sistem Pendidikan Nasional, Pasal 3 dijelaskan bahwa tujuan pendidikan nasional adalah mengembangkan potensi peserta didik agar menjadi manusia yang beriman dan bertakwa kepada Tuhan Yang Maha Esa, berakhlak mulia, sehat, berilmu, cakap, kreatif, mandiri, dan menjadi warga negara yang demokratis serta bertanggung jawab. Untuk mencapai tujuan pendidikan tersebut, kualitas guru menjadi salah satu faktor penentu keberhasilan peserta didik dalam proses belajar mengajar. Kinerja guru memiliki kontribusi yang cukup besar dalam mengembangkan potensi peserta didik di sekolah.

Motivasi guru memiliki dampak/ implikasi terhadap pemimpin dan pengelola sekolah karena motivasi guru juga berpengaruh terhadap motivasi peserta didik. Guru dengan tingkat motivasi yang tinggi akan mampu menciptakan lingkungan sosial dan psikologi yang lebih baik untuk peserta didik. Oleh karena itu, motivasi guru juga merupakan kunci keberhasilan kinerja organisasi atau sekolah.

Bukti empiris menunjukkan terdapat hubungan yang kuat diantara kompensasi dan kualitas guru. Penelitian yang ada mengindikasikan bahwa kompensasi berpotensi untuk meningkatkan kinerja guru. Kompensasi 
yang diterima oleh guru baik berupa financial ataupun non finanasial juga akan berdampak kepada kepuasan kerja. Guru yang memiliki kepuasan kerja bagus maka akan terus menunjukkan kinerja yang maksimal.

Motivasi dan kompensasi merupakan faktor yang berpengaruh terhadap kinerja guru. Motivasi menjadi poin yang penting mengingat tanggung jawab guru adalah menyampaikan ilmu pengetahuan dan keterampilan kepada peserta didik. Sedangkan tujuan dari kompensasi yang baik adalah untuk menarik, memotivasi dan mempertahankan orang-orang yang berkinerja baik untuk pencapaian tujuan organisasi. Kompensasi yang diberikan kepada individu merupakan suatu bentuk apresiasi jasa dan upaya dalam menyelesaikan tugas dan pekerjaan mereka. Saat ini negara maju dan berkembang mengalami kekurangan guru berkualitas di bidang pendidikan. Sebagai factor penting dalam keberhasilan dalam pembelajaran, guru seharunya memiliki kinerja yang bagus. Sekolah Menengah Kejuruan (SMK) adalah salah satu lembaga pendidikan di Indonesia yang berperan dalam menghasilkan lulusan yang memiliki kompetensi siap kerja. Sehingga, kualitas SMK sangat menentukan mutu Sumber Daya Manusia (SDM) bangsa Indonesia. Data (Dikbud, 2016) menunjukkan bahwa kinerja guru SMK masih dalam kategori kurang yaitu dnegan nilai masih kurang yaitu $77.60 \%$.

Berdasarkan penelitian sebelumnya
yang dilakukan oleh (Nowsu, 2016) kompensasi memiliki pengaruh terhadap motivasi guru di sekolah negeri. Penelitian ini juga menyatakan bahwa motivasi juga berpengaruh terhadap kinerja guru di sekolah negeri di Kenya.Selain itu, berdasarkan hasil penelitian (Sukrapi, 2014) menunjukkan bahwa motivasi kerja guru berpengaruh positif dan signifikan terhadap kinerja guru.

Dari data rendahnya kinerja guru SMK yang dikeluarkan oleh Kemendikbud dapat dilihat bahwa secara umum kualitas guru SMK masih memiliki kinerja yang kurang. Penelitian sebelumnya yang sudah pernah dilakukan terkait motivasi merupakan penelitian yang dilakukan untuk mengetahui kinerja guru di sekolah negeri. Kompensasi yang diberikan kepada guru negeri memiliki system yang berbeda dengan sistem kompensasi yang diberikan kepada guru swasta. Oleh karena itu peneliti ingin mengetahui pengaruh motivasi dan kompensasi terhadap kinerja guru SMK swasta di kecamatan bangil. Adapun tujuan dari penelitian ini adalah untuk mengukur seberapa besar pengaruh motivasi kerja dan kompensasi terhadap kinerja guru SMK Swasta seKecamatan Bangil?

\section{METODE PENELITIAN}

Penelitian ini merupakan penelitian kuantitatif deskriptif dengan metode survey. Penelitian ini dilaksanakan di 5 SMK di Bangil dengan subyek penelitian ini adalah 3 orang guru dari tiap jurusan pada setiap sekolah. Setiap guru akan mengisi dan menjawab kuesioner yang telah disebarkan. Metode penarikan sampel yang digunakan adalah menggunakan Central Limit Teorema (sebuah teorema yang menyatakan bahwa kurva distribusi sampling untuk ukuran sampel 30 atau lebih akan berpusat pada nilai parameter populasi dan akan memiliki semua sifat-sifat distribusi normal). Agar tidak berpusat pada satu titik maka digunakan metode cluster random sampling dengan mengambil 3 guru dari tiap jurusan yang ada di sekolah masingmasing sehingga jumlah sample yang diambil dari populasi yang ada sebanyak 42 guru dari 5 sekolah yang terbagi 14 jurusan.

Dalam penelitian ini akan digunakan uji validitas product moment dan uji reliabilitas croanbach's alpha dengan bantuan software SPSS for windows versi 21. Teknik analisis data yang digunakan untuk menguji dalam penelitian ini yaitu Regresi Linier Berganda untuk menguji apakah ada pengaruh variabel motivasi dan kompensasi terhadap kinerja guru. 
Desian penelitian ini akan mengukur variable motivasi dan kompensasi secara bersama-sama terhadap kinerja.

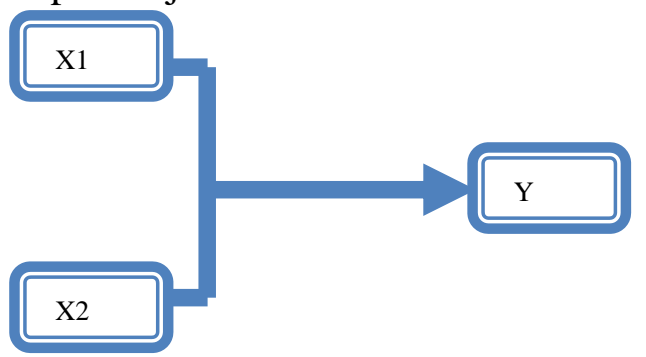

Gambar 1.1 Pengaruh Variabel X1 dan X2 terhadap Y
Keterangan:

$\mathrm{X} 1 \quad$ : Motivasi Kerja

X2 : Kompensasi Guru

Y : Kinerja Guru

\section{HASIL DAN PEMBAHASAN \\ Hasil Penelitian}

Hasil dari analisis data menggunakan spps diperoleh hasil regresi ganda seperti tabel 1.1 dibawah ini.

Tabel 1.1 Analisis Persamaan Linier Regresi Ganda

\begin{tabular}{|c|c|c|c|c|c|}
\hline \multicolumn{6}{|c|}{ Coefficients $^{a}$} \\
\hline \multirow{2}{*}{ Model } & \multicolumn{2}{|c|}{ Unstandardized Coefficients } & Standardized Coefficients & \multirow{2}{*}{$\mathrm{t}$} & \multirow{2}{*}{ Sig } \\
\hline & B & Std. Error & Beta & & \\
\hline Constant & 3.684 & 2.826 & & 1.304 & .200 \\
\hline 1 Tot Mot & .359 & .079 & .367 & 4.530 & .000 \\
\hline Tot Komp & 1.096 & .138 & .645 & 7.972 & .000 \\
\hline
\end{tabular}

Dari tabel diatas, persamaan linier regresi ganda Kinerja Guru (Y) dalam Motivasi Kerja (X1) dan Kompensasi Guru (X2) adalah sebagai berikut :

$$
\mathrm{Y}=3,684+0,0356 \mathrm{X} 1+1,096 \mathrm{X} 2
$$

Karena untuk motivasi kerja $\mathrm{t}_{\text {hit }}=4,530$ $>1.68=\mathrm{t}$ 0,05;39, maka motivasi berpengaruh signifikan terhadap kinerja guru. Begitu juga untuk kompensasi guru, $\mathrm{t}_{\text {hit }}=7,972>1.68=\mathrm{t}$ 0,05;39, maka kompensasi guru berpengaruh signifikan terhadap kinerja guru.

\begin{tabular}{|lrrrrr|}
\hline ANOVA $^{\mathrm{a}}$ & & & & \\
\hline Model & Sum of Squares & df & Mean Square & $\mathrm{F}$ & Sig. \\
\hline \multicolumn{1}{|c|}{ Regression } & 621.882 & 2 & 310.941 & 102.253 & $.000^{\mathrm{b}}$ \\
1 & Residual & 118.595 & 39 & 3.041 & \\
\\
Total & 740.476 & 41 & & & \\
\hline
\end{tabular}

Dari tabel diatas terlihat $\mathrm{F}$ hit $=102,253$ $>3,23=\mathrm{F} 0,05(2 ; 39)$, maka regresi linier ganda signifikan.

\section{Pembahasan}

Berdasarkan data analisis, diperoleh hasil bahwa motivasi kerja dan kompensasi guru secara bersama-sama berpengaruh terhadap kinerja guru SMK Swasta sekecamatan Bangil. Motivasi guru sangat penting untuk menumbuhkan dan mengembangkan proses pembelajaran yang baik di dalam kelas. Motivasi guru di sekolah 190 mengacu kepada penguasaan konsep dan keterampilan mengajar di dalam kelas. Semakin tinggi motivasi guru untuk mengajar, guru akan menunjukkan kemampuan optimal di dalam kelas sehingga kinerjanya akan terus meningkat.

Kompensasi dan insentif finansial yang diberikan kepada guru merupakan factor penting dalam persaingan yang kompetitif di antara SMK swasta yang ada, bentuk lain pemberian kompensasi berupa kesempatan guru untuk mengikuti pelatihan dan 
pengembangan diri juga sangat berpengaruh terhadap kinerja guru. Guru yang memiliki kinerja bagus, melaksanakan tugas pembelajaran di kelas dengan baik didukung dengan teknikal skills atau kompetensi yang bagus. Artinya pemberian kompensasi baik dalam bentuk finasial ataupun pelatihan keduanya sangat berpengaruh terhadap kinerja guru di sekolah. Hasil tersebut sesuai dengan pendapat (Hasibuan,2008) yang mendefinisikan motivasi sebagai suatu perangsang (want) dan daya penggerak kemauan bekerja seseorang.

Motivasi dan kompensasi merupakan dua variabel penting dalam mempengaruhi tinggi rendahnya kinerja guru. Keinginan guru untuk mengajar dengan baik di kelas serta didukung pemberian kompensasi pelatihan peningkatan kompetensi dari sekolah akan memberikan dampak yang sangat positif terhadap kinerja guru di sekolah.

Selain itu, penelitian ini juga membuktikan bahwa kompensasi guru berpengaruh positif juga terhadap kinerja guru SMK Swasta se-Kecamatan Bangil. Semakin besar atau tinggi kompensasi yang diberikan oleh sekolah terhadap guru maka akan semakin tinggi dan baik pula kualitas kinerja guru. Hal ini sejalan dengan pendapat Handoko (2008:157) kompensasi hendaknya mendorong perilaku-perilaku yang diinginkan. Prestasi kerja yang baik, pengalaman, kesetiaan, tanggung jawab baru dan perilaku-perilaku lain dapat dihargai melalui rencana kompensasi yang efektif.

Seorang guru yang memiliki tingkat motivasi bagus akang sangat membantu dan memudahkan organisasi dalam meraih tujuan organisasi. Guru dengan tingkat motivasi yang tinggi akan melaksanakan tugas pengajaran dengan sebaik mungkin kepada peserta didik. Begitu pula sebaliknya, guru dengan tingkat motivasi yang rendah akan berdampak kepada kualitas pengajaran yang diberikan kepada peserta didik. Hampir sebagian besar SMK swasta di Bangil merupakan sekolah SMK dalam pengelolaan SDM nya sudah terstruktur. Beberapa guru yang direkrut merupakan guruguru yang memiliki kompetensi sesuai dengan bidang yang diampunya dan juga merupakan lulusan dari universitas yang bereputasi.

Selain input SDM yang cukup memiliki kualifikasi dan motivasi yang bagus, sistem kompensasi di beberapa sekolah SMK memang sudah baik.

\section{SIMPULAN DAN SARAN Simpulan}

Hasil penelitian ini menunjukkan hasil yang signifikan korelasi antara motivasi dan kompensasi terhadap kinerja guru. Pengaruh motivasi kerja dan kompensasi terhadap kinerja guru SMK Swasta se-Kecamatan Bangil positif dan signifikan sebesar $83,98 \%$. Jika semakin tinggi motivasi kerja yang dimiliki dan kompensasi yang diterima oleh guru maka kinerja guru SMK swasta se-Kecamatan Bangil semakin tinggi.

\section{Saran}

Adapun saran untuk peneliti kedepannya adalah bahwa ruang lingkup studi ini difokuskan pada guru SMK Swasta seKecamatan Bangil yang berdampak pada generalisasi studi yang terbatas. Keterbatasan ini mengisyaratkan perlunya studi studi lanjutan untuk menggeneralisasi hasil-hasil yang diperoleh pada konteks yang berbeda dan lebih luas, sehingga konsep-konsep yang diuji dalam model dapat ditingkatkan validitas eksternalnya.

\section{DAFTAR PUSTAKA}

Afifah, Marnesya. (2011). Pengaruh Motivasi, Kompensasi, dan Pengembangan Karir terhadap Kinerja Guru (Studi Kasus Pada SMK Nusantara Jl. Tarumanegaran dalam No.1 Ciputat). Jakarta : UIN Syarif Hidayatullah. 
Arikunto, Suharsimi. (1999). Prosedur Penelitian: Suatu Pendekatan Praktek. Yogyakarta: Rineka Cipta.

Fauzie, Ahmad. (2009). Pengaruh Motivasi dan Kompensasi Terhadap Kinerja Pegawai Perpustakaan UIN Syarif Hidayatullah Jakarta (Tesis). Jakarta : UIN Syarif Hidayatullah.

Ghozali, Imam. (2005). Aplikasi Analisis Multivariate dengan Program SPSS. Semarang: Universitas Diponegoro.

Handoko, T. Hani. (2008). Manajemen Personalia \& Sumberdaya Manusia. Yogyakarta: BPFE.

Hasibuan, Malayu S.P. (2008). Manajemen Sumber Daya Manusia. Jakarta : Penerbit Bumi Aksara.

Kadarisman, M (2012). Manajemen Kompensasi. Jakarta : Rajagrafindo Persada.

Keran, Kristina N. (2012). Pengaruh Motivasi Kerja, Kompetensi, Kompensas dan Kinerja Karyawan di Yayasan Bintang Timur Tangerang (Tesis). Jakarta : Universitas Esa Unggul.
Mulyasa. (2013). Uji Kompetensi dan Penilaian Kerja Guru. Bandung : PT. Remaja Rosdakarya.

Nowsu, J (2016). Motivation And Teachers' Performance In Selected Public Secondary Schools In Ikenne Local Government Area of Ogun State.. British Journal of Psychology Research Vol.5, No.3, pp 40-50.

Robbins, Stephen P. (2002). Prinsip-prinsip Perilaku Organisasi. Jakarta : Erlangga.

Robbins, Stephen P dan Timothy A. Judge. (2009). Perilaku Organisasi Organizational Behavior Edisi 12. Jakarta : Salemba Empat.

Sarimaya, Farida. (2008). Sertifikasi Guru. Jakarta : Yrama Widya.

Wekesa, Jane N, dan Silas Nyaroo. (2013). "Effect of Compensation on Performance of Public Secondary School Teachers in Eldort Municipality Kenya". International Journal of Scientific and Research Publications (ISSN 2250-3153) Vol. 03 - Issue 6, June 2013. 